\title{
Immobilization of commercial inulinase on alginate-chitosan beads
}

\author{
Juliano Missau, Amir J Scheid, Edson L Foletto, Sergio L Jahn, Marcio A Mazutti and Raquel C Kuhn*
}

\begin{abstract}
The commercial inulinase obtained from Aspergillus niger was effectively immobilized on alginate-chitosan beads which were hardened with glutaraldehyde. The immobilization conditions were studied using Plackett \& Burmann experimental design and central composite rotational design (CCRD). The effects of chitosan, glutaraldehyde, sodium alginate and calcium chloride concentrations in order to obtain a better immobilization yield were optimized. In the Plackett \& Burman experimental design, the sodium alginate and calcium chloride had a significant effect ( $p<0.1)$, but only the calcium chloride showed a positive effect, indicating that as higher the concentration, better is the immobilization yield. In the central composite rotational design (CCRD), the best results were obtained in the central point, using sodium alginate $(1 \% \mathrm{w} / \mathrm{v})$ and calcium chloride $(4 \% \mathrm{w} / \mathrm{v})$ as conditions for inulinase immobilization. By the CCRD, the optimal immobilization strategy was: chitosan $(0.1 \% \mathrm{w} / \mathrm{v})$, glutaraldehyde $(0.1 \% \mathrm{v} / \mathrm{v})$, sodium alginate $(1 \% \mathrm{w} / \mathrm{v})$ and calcium chloride $(4 \% \mathrm{w} / \mathrm{V})$. In this condition, the enzyme loading capacity was $668 \mathrm{U} / \mathrm{g}$ gel beads and the effect of temperature on the immobilized enzyme activity was also evaluated, showing better activity at $50^{\circ} \mathrm{C}$. The immobilized enzyme maintained $76 \%$ of its activity in six days at room temperature.
\end{abstract}

Keywords: Inulinase, Immobilization, Glutaraldehyde, Chitosan, Experimental design

\section{Introduction}

Inulinases are enzymes potentially useful on the production of high fructose syrups (HFS) by enzymatic hydrolysis of inulin, conducting to a yield of $95 \%$ [1]. Inulinases are enzymes widely used for the production of fructooligosaccharides, compounds with functional and nutritional properties for use in low-calorie diets, stimulation of Bifidus and as a source of dietary fiber in food preparations [2].

Enzyme immobilization increases the catalytic properties of enzyme, allow the continuous reuses of costly enzyme to make it economically viable for industrial applications [3,4]. The enzymes immobilization is usually carried out by three methods: covalent binding to a supports, adsorption of enzyme molecules on a support material and entrapment or encapsulation of enzyme in polymers. The covalent binding and adsorption methods both have disadvantages because they have possibility to affect the substrate binding site of enzyme and enforce diffusion limitation on the enzyme which ultimately

\footnotetext{
* Correspondence: raquelckuhn@yahoo.com.br

Department of Chemical Engineering, Federal University of Santa Maria,
} Santa Maria 97105-900, Brazil causes the decrease in enzyme activity [4]. Entrapment is one step process in which chances of activity lost is comparatively low. Polymers such as alginate were used for entrapment of enzymes $[4,5]$.

Calcium alginate hydrogel beads are commonly used carriers in the entrapment immobilization of biocatalyst [5] owing to their significant advantages such low cost, high porosity, and simplicity of preparation, however, this material has some limitations these are due to biocompatibility, including high biomolecule leakage, and large pore size $[5,6]$. For the encapsulation efficiency and control release of enzyme from the gel matrix, the covalent cross-linking with polymers, such as chitosan, and coating the surface of alginate gel beads with other reagents, such as glutaraldehyde, have been used [5].

This study was based on immobilization of commercial inulinase from Aspergillus niger within alginate-chitosan beads. In order to obtain a better immobilization yield, the immobilization parameters such as chitosan, glutaraldehyde, sodium alginate and calcium chloride concentrations were optimized. The Plackett \& Burman and central composite rotational design (CCRD) were employed to evaluate the effects of immobilization parameters. 
Thermal and storage stabilities were also evaluated in this work.

\section{Material and methods Material}

The commercial inulinase was purchased from SigmaAldrich, which was obtained from Aspergillus niger (Fructozyme, exo-inulinase EC 3.2.1.80 and endo-inulinase EC 3.2.1.7). The chitosan was purchased from Purifarma (Brazil) and others reagents from Vetec (Brazil).

\section{Enzyme immobilization}

For the inulinase immobilization protocol, a methodology adapted from Zhou et al. [5] was used: alginate was dissolved in water and the equal volume inulinase enzyme solution (1:100, enzyme:acetate buffer) was added by mild shaking on a rotary shaker. Chitosan was ultrasonically dispersed in an acetic acid solution (5\% v/v) for $1 \mathrm{~h}$ and $\mathrm{CaCl}_{2}$ solution was added. Alginate/inulinase mixture was extruded dropwise through a peristaltic pump into a $50 \mathrm{~mL}$ chitosan/ $\mathrm{CaCl}_{2}$ solution and hardened in this solution. The formed spherical beads were rinsed with sterile $\mathrm{NaCl}$ solution $(0.9 \% \mathrm{w} / \mathrm{v})(2 \times 20 \mathrm{~mL})$ and then treated with glutaraldehyde solution for $2 \mathrm{~h}$. The immobilized inulinase was washed thrice with sterile distilled water and then directly used for the measurements of activity and stability.

\section{Inulinase activity assay}

An aliquot of $0.5 \mathrm{~g}$ of the enzyme was incubated with $4.5 \mathrm{~mL}$ sucrose solution $(2 \% \mathrm{w} / \mathrm{v})$ in sodium acetate buffer $(0.1 \mathrm{M}, \mathrm{pH} 4.8)$ at $50^{\circ} \mathrm{C}$. Reducing sugars released were measured by the 3.5-dinitrosalicylic acid method [7]. A separate blank was set up for each sample to correct the non-enzymatic release of sugars. One unit of inulinase activity was defined as the amount of enzyme necessary to hydrolyze $1 \mu \mathrm{mol}$ of sucrose per minute under the mentioned conditions (sucrose as a substrate). Results were expressed in terms of inulinase activity (enzyme loading) per gram of gel beads (U/g).

At each step, the pellets were washed with distilled water to remove the excess of glutaraldehyde and unbound enzyme. The immobilization yield (Y\%) was determined as defined in the Equation 1:

$$
Y(\%)=\frac{\text { activity immobilization enzyme }}{\text { activity free enzyme }} \times 100
$$

The amount of protein loaded on the support was calculated from the difference of initially added protein to the protein obtained in the washing plus supernatant. The protein content was determined by Biuret method using bovine serum albumin as a standard [8].
Table 1 Matrix of Plackett \& Burman experimental design

\begin{tabular}{lccc}
\hline Independent & \multicolumn{3}{c}{ Coded levels of variables } \\
\cline { 2 - 4 } variables & $\mathbf{- 1}$ & $\mathbf{0}$ & $\mathbf{+ 1}$ \\
\hline Chitosan (\%) & 0.1 & 0.25 & 0.4 \\
Glutaraldehyde (\%) & 0.1 & 0.50 & 0.9 \\
Sodium alginate (\%) & 1 & 3 & 5 \\
$\mathrm{CaCl}_{2}(\%)$ & 1 & 2 & 3 \\
\hline
\end{tabular}

The immobilization efficiency was defined in the Equation 2:

$$
E(\%)=\frac{\text { specific activity bound to the support }}{\text { specific activity initially added }} \times 100
$$

\section{Experimental design}

The effects of chitosan $(0.1-0.4 \% \mathrm{w} / \mathrm{v})$, glutaraldehyde $(0.1-0.9 \% \mathrm{v} / \mathrm{v})$, sodium alginate $(1-5 \% \mathrm{w} / \mathrm{v})$ and calcium chloride $(1-3 \% \mathrm{w} / \mathrm{v})$ were assessed by means a Plackett \& Burman for four independent variables. Table 1 presents the range of investigated variables. The significance variables in the Plackett \& Burman were studied in the central composite rotational design (CCRD). All the results were analyzed using the software Statistica ${ }^{\circ} 8.0$ (Statsoft Inc., Tulsa, USA).

\section{Thermal stability}

The stability was determined by incubation of immobilized enzyme in $0.1 \mathrm{M}$ acetate buffer ( $\mathrm{pH} 4.8$ ) without substrate at 30,50 and $70^{\circ} \mathrm{C}$. Samples were taken at different intervals during 4 hours and the inulinase activity was determined. The relative activity at each temperature was determined by taking the activity at $0 \mathrm{~min}$ as $100 \%$.

\section{Shelf stability}

The shelf stability was determined by incubation of immobilized enzyme in $0.1 \mathrm{M}$ acetate buffer ( $\mathrm{pH} 4.8$ ) without substrate at room temperature $\left(25^{\circ} \mathrm{C}\right)$. Samples were taken at different intervals and the inulinase activity was determined. The relative activity at each temperature was determined by taking the activity at $0 \mathrm{~min}$ as $100 \%$.

Table 2 Effects of Plackett \& Burman experimental design for immobilization yield

\begin{tabular}{lcccc}
\hline & Effects & Error & $\mathbf{t}(\mathbf{6})$ & p-value \\
\hline Mean & 27.125 & 0.896 & 30.261 & $<0.0000008$ \\
Chitosan (\%) & 3.858 & 2.102 & 1.835 & 0.1161 \\
Glutaraldehyde (\%) & 1.851 & 2.102 & 0.881 & 0.4124 \\
Sodium alginate (\%) & -7.531 & 2.102 & -3.582 & 0.01161 \\
Calcium chloride (\%) & 6.637 & 2.102 & 3.157 & 0.01963 \\
\hline
\end{tabular}




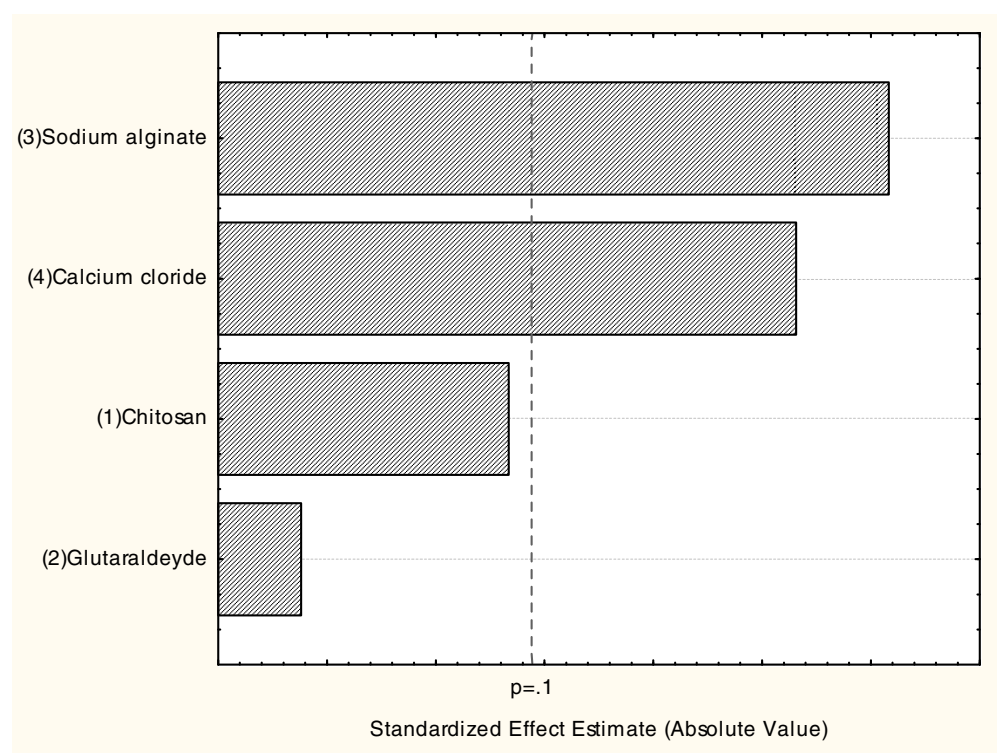

Figure 1 Pareto Chart for the variables independents in the Plackett \& Burman experimental design.

\section{Results and discussion}

\section{Plackett \& burman}

In large-scale processes, the enzyme can be immobilized and the process cost is very important. Therefore, the conditions for the inulinase immobilization were studied in this work. The enzyme immobilization on alginate beads is not only inexpensive, but also used in mild conditions [5]. So, the sodium alginate has been considered for the entrapment of enzymes due many advantages [5].

In the preliminary experiments, the main variables (chitosan, glutaraldehyde, calcium chloride, sodium alginate) that could influence on the immobilization yield were studied through Plackett \& Burman experimental design for the optimization of inulinase immobilization. Table 2 and Pareto Chart (Figure 1) showed that only the sodium alginate and calcium chloride had a significant

Table 3 Results of inulinase immobilization using central composite rotational design

\begin{tabular}{cccc}
\hline Assays & Sodium alginate & Calcium chloride & $\mathbf{Y}(\%)$ \\
\hline 1 & $-1(0.5)$ & $-1(3)$ & 13.58 \\
2 & $-1(0.5)$ & $+1(5)$ & 25.52 \\
3 & $+1(1.5)$ & $-1(3)$ & 22.11 \\
4 & $+1(1.5)$ & $+1(5)$ & 30.73 \\
5 & $0(1)$ & $-1.41(2.6)$ & 25.34 \\
6 & $0(1)$ & $+1.41(5.4)$ & 24.45 \\
7 & $-1.41(0.3)$ & $0(4)$ & 11.11 \\
8 & $+1.41(1.7)$ & $0(4)$ & 18.10 \\
9 & $0(1)$ & $0(4)$ & 36.38 \\
10 & $0(1)$ & $0(4)$ & 39.48 \\
11 & $0(1)$ & $0(4)$ & 36.63 \\
\hline
\end{tabular}

effect at $90 \%$ of confidence $(\mathrm{p}<0.1)$ on the inulinase immobilization yield. The sodium alginate had a negative effect, meaning that as lower the sodium alginate concentration, better is the immobilization yield. On the other hand, the calcium chloride showed a positive effect, indicating that as higher the concentration, better is the immobilization yield. The chitosan and glutaraldehyde were not statistically significant within the levels studied.

Considering the Plackett \& Burman experimental design results, an additional set of experiments were carried out according to a central composite rotational design (CCRD) in order to find the optimal conditions for the inulinase immobilization. The variables real and

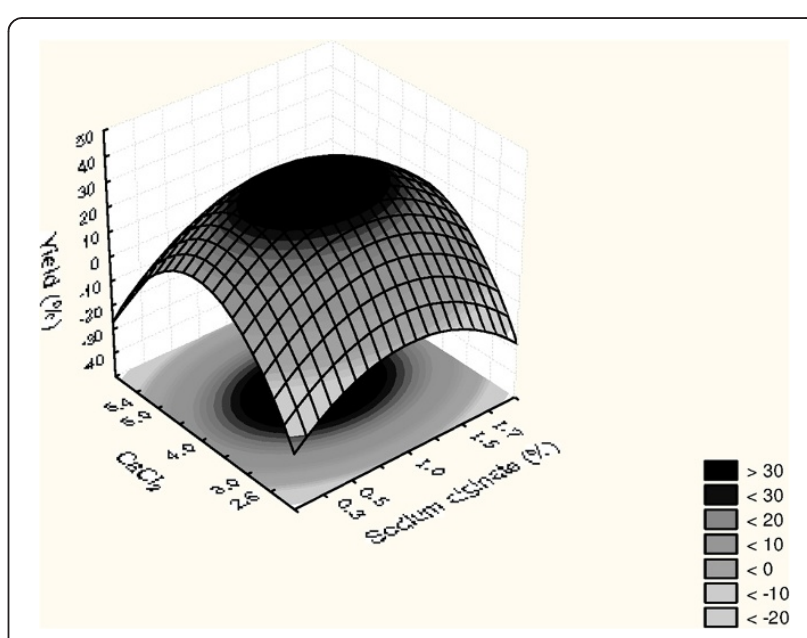

Figure 2 Response surface for the inulinase immobilization according to the central composite rotational design. 
Table 4 ANOVA for inulinase immobilization

\begin{tabular}{lccccc}
\hline & SS & $\boldsymbol{d f}$ & $\mathbf{M S}$ & $\mathbf{F}$ & $\mathbf{R}^{\mathbf{2}}$ \\
\hline Regression & 672.26 & 2 & 336.13 & 12.88 & 76.3 \\
Residual & 208.65 & 8 & 26.08 & & \\
Total & 880.91 & 10 & & & \\
\hline
\end{tabular}

$\mathrm{F}_{0.05 ; 2 ; 8}=4.46$.

coded were presented in the Table 3 . The variables chitosan and glutaraldehyde were fixed at $0.1 \%$ in the central composite rotational design.

The glutaraldehyde cross-links enzyme and gelatin forming an insoluble structure. Glutaraldehyde treatment also stabilizes the alginate gel, helping in the prevention of the leakage of enzymes [9]. In this work, it was used to maintain the stable beads. At the concentration studied, the glutaraldehyde showed no significant influence on the response, but according to the results, it was possible to conclude that the glutaraldehyde is especially important for the stability of the enzyme, even at low concentrations studied $(0.1 \% \mathrm{v} / \mathrm{v})$.

\section{Central composite rotational design $\left(2^{2}\right)$}

The better results concerning the CCRD were obtained in the central point (Table 3). According to these results, the best conditions for the inulinase immobilization yield were observed using sodium alginate $(1 \% \mathrm{w} / \mathrm{v})$ and calcium chloride $(4 \% \mathrm{w} / \mathrm{v})$. The effect of calcium chloride concentration is important to secure stable calcium alginate beads with maximum immobilization yield [4].

The enzyme immobilization presented activity values lower than those obtained for the free enzyme. Cheirsilp et al. [10] and Zhou et al. [5] reported a decrease of enzyme activity in immobilized alginate beads, similar to the observed in this work. The decrease in the immobilized enzyme activity could be explained due to

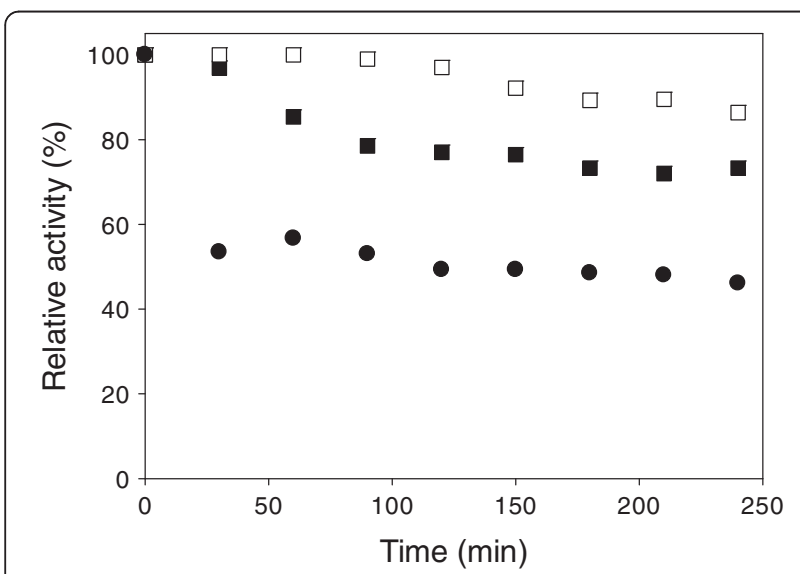

Figure 3 Thermal stability of immobilized enzyme $\left((\square) 30^{\circ} \mathrm{C},(\square)\right.$ $50^{\circ} \mathrm{C}$ and $\left.(\bullet) 70^{\circ} \mathrm{C}\right)$.

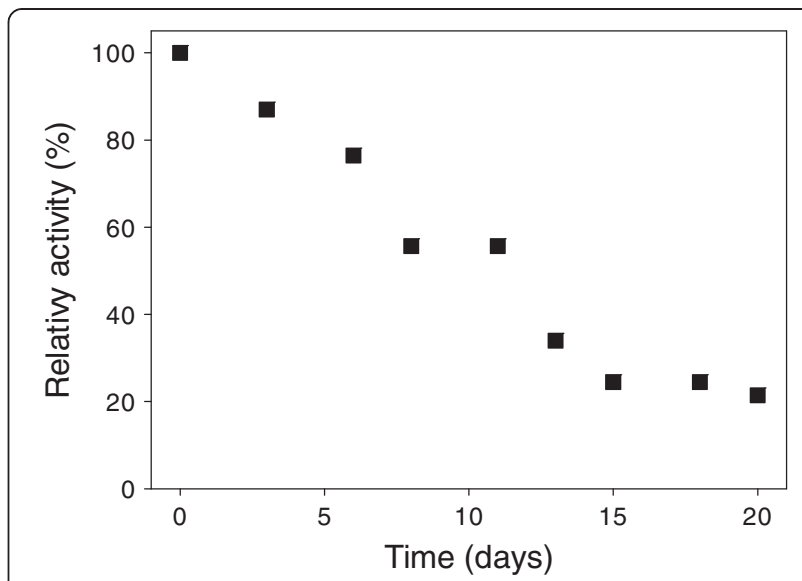

Figure 4 Shelf stability of immobilized inulinase during storage at room temperature.

diffusional limits, steric effects, structural changes in the enzyme occurring upon covalent coupling, or lowered accessibility of substrate to the active site of the immobilized enzyme [11].

The enzyme loading capacity i.e., enzyme per gram of gel beads, was $668 \mathrm{U} / \mathrm{g}$ in the best condition of the CCRD. Danial et al. [12] obtained $530 \mathrm{U} / \mathrm{g}$ and $336 \mathrm{U} / \mathrm{g}$ gel using one and two-step method on grafted alginate, respectively. The crude inulinase was assayed for its activity and protein content, the specific activity was calculated according Eq. 2 and was 66\%.

The results obtained in the central composite rotational design were used to build the quadratic models expressing the inulinase immobilization yield as functions of the independent variables.

Based on statistical analysis of model parameters, one empirical model was presented below (Eq. 3). Coded model (Eq. 3) was used to generate response surface (Figure 2) for the analysis of the variables effects on the immobilization. It presents the significant terms $(\mathrm{p}<0.05)$ concerning of inulinase immobilization yield and it was

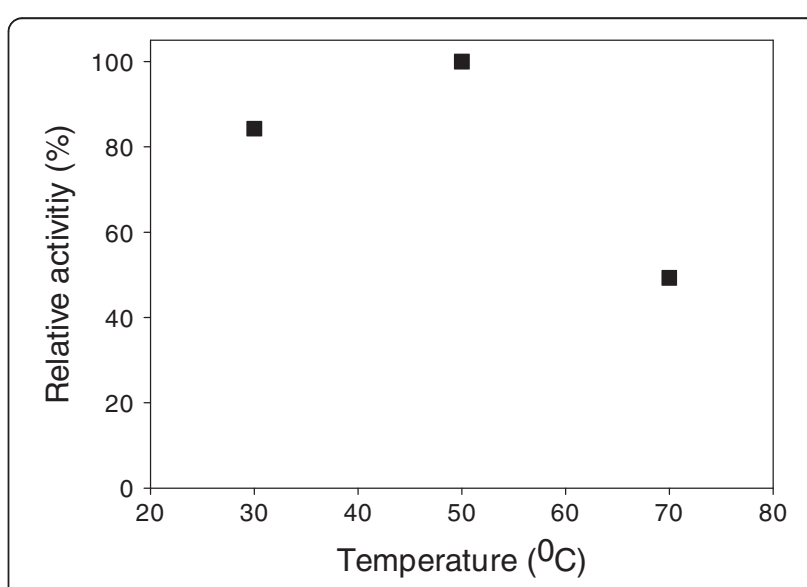

Figure 5 The effect of temperature on enzyme activity. 
validated by analysis of variance (ANOVA), which was presented in Table 4. According to the ANOVA analysis of the immobilization, the calculated $\mathrm{F}$ was about 2.9 times greater than the tabulated ones and the determination coefficient was 0.76 . The high values for the determination coefficient indicate good fitting of experimental data, allowing the use of such models to predict process performance. For the biotechnological process, this determination coefficient is acceptable because of the high variability in the bioprocess.

$$
Y(\%)=37.48-5.49 X_{1}{ }^{2}-10.66 X_{2}{ }^{2}
$$

Where $X_{1}$ is the sodium alginate and $X_{2}$ is the calcium chloride.

The validated model was used to optimize the process using the tool response/desirability profiling of Statistica 8.0. The desirability function allows the response surface produced be inspected by fitting the observed responses using the above mentioned equation based on levels of the independent variables. This equation was used to predict values for response (inulinase immobilization yield) at different combinations of levels of the independent variables, specify desirability functions for the dependent variables, and to search for the levels of the independent variables that produce the most desirable responses for the dependent variables (immobilization yield) [13].

\section{Thermal and shelf stabilities}

The optimum temperature of immobilized enzyme was $50^{\circ} \mathrm{C}$. According to Figure 3, it is clear that in the temperature of $50^{\circ} \mathrm{C}$ the relative activity of immobilized enzyme was considerably higher compared with other temperatures studied $\left(30\right.$ and $\left.70^{\circ} \mathrm{C}\right)$. Rocha et al. [14] achieved maximum activities for immobilized inulinase onto Amberlite IRC 50 at $50^{\circ} \mathrm{C}$. Danial et al. [12] and Yewale et al. [15] found $60^{\circ} \mathrm{C}$ as the best temperature for the immobilized inulinase on grafted alginate and chitosan, respectively. Richeti et al. [16] observed optimum values for immobilization at $55^{\circ} \mathrm{C}$. In this work, in the temperature of $70^{\circ} \mathrm{C}$ was observed that beads did not maintain the structure and weakened. The results revealed that at $50^{\circ} \mathrm{C}$ and after 4 hours the immobilized enzyme activity retained $86.5 \%$ of its activity.

The data shown in Figure 4 indicated that the immobilized enzyme retained over $76 \%$ of its activity in six days at room temperature. However, this storage stability could be improved at lower temperatures, e.g. $4-5^{\circ} \mathrm{C}$. The immobilized enzyme lost practically all of its activity at room temperature after 20 days; the relative activity was $20 \%$.

In the Figure 5 was observed that the temperature of $50^{\circ} \mathrm{C}$ maintained $100 \%$ of relative activity during
120 minutes, and at $30^{\circ} \mathrm{C}$ and $70^{\circ} \mathrm{C}$ around $80 \%$ and $50 \%$ of relative activity was maintained, respectively.

\section{Conclusion}

Inulinase immobilization could be carried out successfully using alginate-chitosan beads hardened with glutaraldehyde. By the Plackett \& Burman experimental design only the variables sodium alginate and calcium chloride presented significant effect $(\mathrm{p}<0.1)$. In the CCRD the optimal immobilization strategy was: chitosan $(0.1 \% \mathrm{w} / \mathrm{v})$, glutaraldehyde $(0.1 \% \mathrm{v} / \mathrm{v})$, sodium alginate $(1 \% \mathrm{w} / \mathrm{v})$ and calcium chloride $(4 \% \mathrm{w} / \mathrm{v})$. In this condition, the optimum temperature in the thermal stability studied was $50^{\circ} \mathrm{C}$ and the inulinase immobilization retained $86.5 \%$ of the relative activity during 240 minutes. The enzyme loading capacity was $668 \mathrm{U} / g$ gel beads, which could be indicating that the inulinase immobilization on the alginate-chitosan beads is a promising technique.

\section{Competing interests}

The authors declare that they have no competing interests.

\section{Authors' contributions}

All authors contributed equally in this work. All authors read and approved the final manuscript.

\section{Acknowledgements}

The authors thank CNPq, CAPES, FAPERGS and Programa FIPE Júnior/UFSM for the financial support of this work and scholarships.

Received: 27 December 2013 Accepted: 19 May 2014 Published: 27 May 2014

\section{References}

1. Ettalibi M, Baratti JC: Sucrose hydrolysis by thermostable immobilized inulinases from Aspergillus ficcum. Enzyme Microb Technol 2001, 28:596-601.

2. Silva-Santisteban BOY, Maugeri F: Agitation, aeration and shear stress as key factors in inulinase production by Kluyveromyces marxianus. Enzyme Microb Technol 2005, 36:717-724.

3. Mateo C, Palomo JM, Fernandez-Lorente G, Guisan JM, Fernandez-Lafuente $\mathrm{R}$ : Improvement of enzyme activity, stability and selectivity via immobilization techniques. Enzyme Microb Technol 2007, 40:1451-1463.

4. Rehman HU, Aman A, Silipo A, Qader SAU, Molinaro A, Ansari A: Degradation of complex carbohydrate: Immobilization of pectinase from Bacillus Licheniformis KIBGE-IB 21 using calcium alginate as a support. Food Chem 2013, 139:1081-1086.

5. Zhou Z, Li G, Li Y: Immobilization of Saccharomyces cerevisiae alcohol dehydrogenase on hybrid alginate-chitosan beads. Int J Biol Macromol 2010, 47:21-26.

6. Smidsrod O, Skjak-Brlk G: Alginate as immobilization matrix for cells. Trends Biotechnol 1990, 8:71-78.

7. Miller GL: Use of dinitrosalisylic acid reagent for determination of reducing sugar. Anal Chem 1959, 31:426-428.

8. Bernardini RD, Harnedy P, Bolton D, Kerry J, O'Neill E, Mullen AM, Hayes M: Antioxidant and antimicrobial peptidic hydrolysates from muscle protein sources and by-products. Food Chem 2011, 134:1296-1307.

9. Ates $S$, Mehmetoglu U: A new method for immobilization of galactosidase and its utilization in a plug flow reactor. Process Biochem 1997, 32:433-436.

10. Cheirsilp B, Jeamjounkhaw $\mathrm{P}$, Kittikun AH: Optimizing an alginate immobilized lipase for monoacylglycerol production by the glycerolysis reaction. J Mol Cat B: Enz 2009, 59:206-211.

11. Ortega N, Perez-Mateos M, Pilar MC, Busto MD: Neutrase immobilization on alginate-glutaraldehyde beads by covalent attachment. J Agric Food Chem 2009, 57:109-115. 
12. Danial EN, Elnashar MMM, Awad GEA: Immobilized inulinase on grafted alginate beads prepared by the one-step and the two-steps methods. Ind Eng Chem Res 2010, 49:3120-3125.

13. Leaes E, Zimmermann E, Souza M, Ramon A, Mezadri E, Dal Prá V, Terra L, Mazutti M: Ultrasound-assisted enzymatic hydrolysis of cassava waste to obtain fermentable sugars. Bio Eng 2013, 115:1-6.

14. Rocha JR, Catana R, Ferreira BS, Cabral JMS, Fernandes P: Design and characterization of an enzyme system from inulin hydrolysis. Food Chem 2006, 95:77-82.

15. Yewale T, Singhal RS, Vaidja AA: Immobilization of inulinase from Aspergillus niger NCIM 945 on chitosan and its application in continuous inulin hydrolysis. Biocatal Agric Biotech 2013, 2:96-101.

16. Richeti A, Munaretto CB, Lerin LA, Batistella L, Oliveira JV, Dallago RM, Astolfi V, Di Luccio M, Mazutti M, de Oliveira D, Treichel H: Immobilization of inulinase from Kluyveromyces marxianus NRRL Y-7571 using modified sodium alginate beads. Bioprocess Biosyst Eng 2012, 35:383-388.

doi:10.1186/2043-7129-2-13

Cite this article as: Missau et al.: Immobilization of commercial inulinase on alginate-chitosan beads. Sustainable Chemical Processes 2014 2:13.

\section{Publish with ChemistryCentral and every scientist can read your work free of charge \\ "Open access provides opportunities to our colleagues in other parts of the globe, by allowing anyone to view the content free of charge." \\ W. Jeffery Hurst, The Hershey Company. \\ - available free of charge to the entire scientific community \\ - peer reviewed and published immediately upon acceptance \\ - cited in PubMed and archived on PubMed Central \\ - yours - you keep the copyright \\ Submit your manuscript here: \\ http://www.chemistrycentral.com/manuscript/<smiles>c1ccccc1</smiles> 